4. The mechanism of the formation and action of the carriers is discussed.

Dr R. Lemberg is thanked for his guidance on several important points, and for providing facilities and accom- modation in the Institute of Medical Research, Royal North Shore Hospital, Sydney; Dr R. N. Robertson for many helpful discussions, and Prof. J. C. Earl, Prof. E. Ashby and Prof. A. Burges for providing facilities and accommodation in the University of Sydney. The work was financed by a grant from the Wellcome Foundation.

\title{
REFERENCES
}

Albert, A. \& Goldacre, R. (1943). J. chem. Soc. p. 454.

Albert, A. \& Goldacre, R. (1944). Nature, Lond., 153, 467. Albert, A. \& Goldacre, R. (1946). J. chem. Soc. p. 706. Albert, A. \& Magrath, D. (1947). Biochem. J. 41, 534. Albert, A., Rubbo, S., Goldacre, R. \& Balfour, B. (1947). Brit. J. exp. Path. 28, 69.

Albert, A., Rubbo, S., Goldacre, R., Davey, M. \& Stone, J. (1945). Brit. J. exp. Path. 26, 160.

Ames, S. R., Ziegenhagen, A. J. \& Elvehjem, A. C. (1946). J. biol. Chem. 165, 81.

Anson, M. L. \& Mirsky, A. E. (1925). J.gen. Physiol. 9, 169. Barron, E. S. G., DeMeio, R. H. \& Klemperer, F. (1936). J. biol. Chem. 112, 625.

Claus, A. \& Howitz, H. (1893). J.prakt. Chem. (2) 47, 426. Fühner, H. (1904). Arch. exp. Path. Pharmak. 51, 391.
Fühner, H. (1906). Arch. exp. Path. Pharmak. 55, 27.

Hall, N. F. \& Sprinkle, M. R. (1932). J. Amer. chem. Soc. 54, 3469.

Keilin, D. \& Hartree, E. F. (1945). Biochem. J. 39, 289.

Lemberg, R., Cortis-Jones, B. \& Norrie, M. (1938). Biochem. J. 32, 149.

Lemberg, R., Legge, J. W. \& Lockwood, W. H. (1939). Biochem. J. 33, 754.

Mathëus, J. (1888). Ber. dtsch. chem. Ges. 21, 1642.

Schönhöfer, F. (1942). Hoppe-Seyl. Z. 274, 1.

Stotz, E., Harrer, C. J., Schultze, M. O. \& King, C. G. (1937). J. biol. Chem. 122, 407.

Tauber, H. (1936). Enzymologia, 1, 209.

Ullmann, F. \& Kipper, H. (1907). Liebigs Ann. 355, 342.

\section{Metabolism of Derivatives of Toluene}

\section{NUCLEAR METHYL-SUBSTITUTED DERIVATIVES OF N-PHENYLUREA}

\author{
BY H. G. BRAY, H. J. LAKE AND W. V. THORPE \\ Department of Physiology, Medical School, University of Birmingham
}

(Received.4 June 1948)

The compounds included in this study were $N$ phenylurea and $N-(o-, m$ - and $p$-tolyl)ureas. The metabolism of these substances does not appear to have been investigated previously, although two drugs which may be regarded as derivatives of $N$ phenylurea have received attention. 'Elbon' (I, $R=\mathrm{C}_{6} \mathrm{H}_{5}$ ) was shown by Morinaka (1922) to be

$$
R . \mathrm{CH}=\mathrm{CH} . \mathrm{CO} . \mathrm{O}=\mathrm{NH} . \mathrm{CONH}_{2}
$$

hydrolyzed in the rabbit to give benzoic acid and $N$-( $p$-hydroxyphenyl)urea, the former being excreted as hippuric acid and the latter as ether glucuronide, which was obtained as a crystalline potassium salt. Tsunoo (1935) showed that 'Ethynal', the corresponding 2-furyl derivative (I, $R=\mathrm{C}_{4} \mathrm{H}_{3} \mathrm{O}$ ) gave rise in the dog to 2 -(2'-furyl)acrylic acid (excreted as such, and as its glycine conjugate) and the glucuronide of $N$-( $p$-hydroxyphenyl)urea; in the rabbit its fate was believed to be similar, although only the glucuronide was isolated. In man the only metabolite identified was furan2-carboxylic acid ( $\alpha$-furoic acid).
There appears to be no account in the literature of the behaviour in vivo of the ureido group (-NH.CO. $\mathrm{NH}_{2}$ ) attached to an aromatic ring, except for the two papers mentioned above, although compounds containing it were often claimed as metabolites of amino compounds by earlier workers. Such 'uramino' compounds include those stated to be derived from sulphanilic acid (Ville, 1892), anthranilic acid (Mitsuba \& Ichihara, 1927), $m$-aminobenzoic acid (Salkowski, 1882) and various aminohydroxybenzoic acids (Pruszynski, 1893). All these compounds were believed to have been formed by the conjugation of urea with the amino group of the substance administered, ammonia being eliminated. These observations have, however, not been repeated in more recent investigations and it now appears likely that the compounds were artefacts, formed during isolation, which, in most early investigations, involved evaporation of the urine to dryness (cf. Schmidt \& Allen (1920) on Salkowski's (1873) uramino compound from taurine; Friedmann (1931) on excretion products of $\alpha$-naphthylalanine and Bray, Lake, Neale, Thorpe \& Wood 
(1948b) on aminobenzoic acids). This process is now rarely used, having been superseded by direct extraction of the urine with ether or other solvents in continuous extractors.

It has been shown that neither acetylation nor alkylation of the amino group of aniline alters the position in which the hydroxyl group enters as a result of biological hydroxylation: aniline and acetanilide both give the para hydroxy derivative and acetanilide also gives the ortho compound (Schmiedeberg, 1878; Müller, 1887; Jaffé \& Hilbert, 1888; Mörner, 1889); $N N$-dimethyl- and $N N$-diethyl-anilines both give para hydroxy derivatives in the rabbit (Horn, 1936, 1937). It was, therefore, of interest to determine whether modification of the amino group as it occurs in $N$-phenylurea derivatives has any influence different from acetylation and alkylation.

The metabolites which might be expected from phenylurea and the tolylureas would be the free amino compounds or their acetyl derivatives, hydroxylated derivatives either free or conjugated with glucuronic or sulphuric acid, and, in the case of the tolylureas, the corresponding benzoic acids formed owing to the oxidation of the methyl group. These acids might be free or conjugated with glucuronic acid or glycine.

The investigation carried out was similar to that described in Part 1 of this series (Bray \& Thorpe, 1948), including a quantitative study of the effects of the four compounds upon the excretion of ethersoluble acid, diazotizable material, glucuronides and ethereal sulphates by the rabbit. Qualitative studies included the isolation of oxidation and hydroxylation products similar in nature to those obtained from the acetotoluidides.

\section{MATERIALS AND METHODS}

Materials. The $N$-phenylurea derivatives necessary for this investigation were readily prepared by the interaction of aqueous solutions of $\mathrm{NaCNO}$ and of the hydrochloride of the corresponding amino compound. It was found that at least three recrystallizations from aqueous ethanol were necessary to give a product which gave a negligible colour on diazotizing and coupling. Commercial preparations ( $N$ - (o- and $m$-tolyl)urea (Genatosan) and $N$-phenylurea (Light and Co.)) required similar treatment. The two $N$. (hydroxymethylphenyl)ureas were prepared from the corresponding aminocresols (Bray \& Thorpe, 1948) and do not appear to have been described previously. N-(4hydroxy-2-methylphenyl)urea formed large colourless prisms, m.p. $232^{\circ}$, which gave a transient weak blue colour with $\mathrm{FeCl}_{3}$; the diazo reaction was negative, although a faint blue colour developed after $30 \mathrm{~min}$. The compound gave no indophenol reaction. (Found: $\mathrm{N}, \mathbf{1 6} \cdot 9 \cdot \mathrm{C}_{8} \mathrm{H}_{10} \mathrm{~N}_{2} \mathrm{O}_{2}$ requires $\mathrm{N}, \quad 16.89 \%$.) N-(4-hydroxy-3-methylphenyl)urea formed white needles, m.p. $203^{\circ}$. It gave a transient faint brown coloration with $\mathrm{FeCl}_{3}$; diazo and indophenol reactions were negative. (Found: $\mathrm{N}, 16 \cdot 9 . \mathrm{C}_{8} \mathrm{H}_{10} \mathrm{~N}_{2} \mathrm{O}_{2}$ requires $\mathrm{N}, 16 \cdot 89 \%$.)
It was found that most phenylurea derivatives on keeping, either as solid or in solution, were hydrolyzed so that diazotizable material could be detected. Table 1 shows results obtained with $N$-phenylurea. The extent of this hydrolysis was somewhat greater in the case of $m$ - and $p$ ureidobenzoic acids and somewhat less with the three tolylureas. It was for this reason that the compounds administered to the rabbits were recrystallized from aqueous ethanol immediately before an experiment. In some cases several recrystallizations failed to give a product entirely free from diazotizable material. Control experiments in which phenylurea derivatives were left standing in normal rabbit urine for $20 \mathrm{hr}$. gave results for free amino compound (by diazo reaction) corresponding to about $2 \%$. It is, therefore, concluded that the free amino values observed in the experimental urines (Tables 2-5) are probably due to spontaneous hydrolysis rather than to any metabolic changes.

\section{Table 1. Spontaneous decomposition of $\mathrm{N}$-phenylurea at $20^{\circ}$}

$\begin{array}{ccc}\begin{array}{c}\text { Time } \\ (\mathrm{hr} .)\end{array} & \begin{array}{c}\text { Aqueous solution } \\ (219 \mathrm{mg} . / 100 \mathrm{ml} .)\end{array} & \begin{array}{c}\text { Solid recrystallized } \\ \text { from aqueous ethanol }\end{array} \\ 0 & - & 0 \\ 0 \cdot 5 & 0 \cdot 5 & - \\ 2 & 0 \cdot 5 & 0 \cdot 4 \\ 19 & 1 \cdot 9 & 0 \cdot 8 \\ 98 & 3 \cdot 2 & 3 \cdot 1 \\ 196 & 7 \cdot 2 & 7 \cdot 7\end{array}$

The two $N$-(hydroxymethylphenyl)ureas are more stable in the solid state. When heated in solution some decomposition occurs, especially with $N$-(4-hydroxy-3-methylphenyl)urea, which could only with difficulty be obtained with the ureido group intact by mild hydrolysis of its glucuronide (see p. 140).

Diet and dosage. The rabbits used were does of $2-3 \mathrm{~kg}$. The diet of rabbit pellets (Bruce \& Parkes, 1946) and water previously described (Bray, Ryman \& Thorpe, 1947) was maintained throughout the study. The compounds investigated were administered by stomach tube as suspensions in water. None of the tolylureas showed any toxic effect at a dose level of $0 \cdot 25-0 \cdot 30 \mathrm{~g} . / \mathrm{kg}$., but phenylurea was appreciably toxic at this level, the rabbits recovering completely in a few hours.

Methods of analysis. These were essentially the same as those used in the acetotoluidide study (Bray \& Thorpe, 1948), but included also estimation of the reducing value of urine hydrolyzed for $1.5 \mathrm{hr}$. with $\mathrm{HCl}$ (cf. Bray, Neale \& Thorpe, 1946). The hydroxylation products formed as metabolites of phenylurea and $o$-tolylurea did not reduce the Shaffer-Hartmann reagent to any appreciable extent either before or after hydrolysis under the conditions used. The hydroxylation product of $m$-tolylurea was, however, slightly reducing after hydrolysis (3.44 mg. $\equiv 1 \mathrm{mg}$. glucose) and allowance for this was made in the same way as for hydroxysulphapyridine (Bray et al. 1946). Estimation of diazotizable material in hydrolyzed urine was not carried out owing to the difficulty of finding conditions which would give quantitative results. The ureido compounds are not completely hydrolyzed under Bratton \& Marshall's (1939) conditions: even a tenfold increase in concentration 
of acid failed to achieve complete hydrolysis. (This is surprising in view of the spontaneous hydrolysis of these compounds already referred to.) The use of this more concentrated acid is attended by the difficulty of adjusting the acidity to that suitable for development of the diazo colour which is retarded or inhibited by excess of acid. Another source of error is that, unless suitable precautions are taken, aniline and toluidine may be lost in steam during hydrolysis, even from acid solution. Finally, there is the complication of the choice of a suitable standard since hydrolysis of the urines may yield more than one diazotizable compound, and the diazo colours given by the compounds differ considerably, e.g. aniline and $p$-aminophenol; toluidine, aminocresol and aminobenzoic acid. The standards used for the diazo estimations, which were performed, were aniline sulphate for phenylurea, $o$-toluidine hydrochloride for $o$ tolylurea and $m$ - and $p$-aminobenzoic acids for the corresponding tolylureas. An attempt was made to devise a method capable of distinguishing between acetamido and ureido compounds, but it was found that even under the mildest conditions necessary for the hydrolysis of the former, the ureido derivatives were hydrolyzed to some extent.

\section{RESULTS}

\section{Quantitative studies}

Excretion of normal metabolites. The average daily excretion of normal metabolites by individual rabbits used in this study was as follows: ether-soluble acid (as hippuric acid), 634-853 mg., the day-to-day variation for each rabbit usually being less than $\pm 7 \%$ of the mean; reducing material (as glucuronic acid), 110-202 mg., the day-to-day variation for each rabbit usually being less than $\pm 13 \%$ of the mean; average increase of reducing material on hydrolysis, $76 \%$; ethereal sulphate, $32-63 \mathrm{mg}$. $\mathrm{SO}_{3}$, the day-to-day variation for each rabbit usually being within $\pm 10 \%$ (i.e. approx. $5 \mathrm{mg} . \mathrm{SO}_{3}$ ) of the mean.

Metabolism of N-phenylurea. Table 2 summarizes the results obtained. It can be seen that an average of $46 \%$ of the dose is hydroxylated and conjugated with sulphuric acid $(20 \%)$ and glucuronic acid $(26 \%)$. The principal hydroxylation product is $N$-( $p$-hyoroxyphenyl)urea and some, at least, is excreted unconjugated, as evidenced by the purple colour which phenylurea urines give with $\mathrm{FeCl}_{3}$. The remainder of the dose is presumably excreted unchanged, but it was not possible to demonstrate this quantitatively, owing to the stability of the ureido group.
Metabolism of o-tolylurea. The quantitative results obtained are given in Table 3. Little or no oxidation of the methyl group occurs, since there is no increase in excretion of ether-soluble acid or ester glucuronide, bat an average of $35 \%$ of the dose is hydroxylated, about $4 \%$ of the resulting $N$-(4-hydroxy-2-methylphenyl)urea being conjugated with sulphuric acid and $31 \%$ with glucuronic acid.

Metabolism of m-tolylurea. As may be seen from Table 4, which contains the quantitative results obtained, an average of $45 \%$ of the dose is oxidized to a carboxylic acid, of which the main part ( $41 \%$ ) is excreted unconjugated and only $4 \%$ as ester glucuronide. In addition hydroxylation takes place (14\%), the product being excreted conjugated as both ethereal sulphate (10\%) and ether glucuronide (14\%). The reducing properties of the hydroxylation product $(N-(4-$ hydroxy-3-methylphenyl)urea) under the conditions of the estimation were allowed for as previously described.

Metabolism of p-tolylurea. Table 5 summarizes the results obtained. About $80 \%$ of the dose is oxidized to $p$-ureidobenzoic acid, of which only a small amount $(6 \%)$ is excreted in conjugated form.

Stability of ureido compounds to rabbit-liver extracts. The experiments described above do not preclude the possibility that slight hydrolysis of the ureido group occurs in vivo. If this does occur it might be expected that extracts of rabbit liver would bring about the hydrolysis in vitro. It was, however, found that incubation of $N$-phenylurea, $N-(p$ hydroxyphenyl)urea, the three tolylureas and $m$ - and $p$ ureidobenzoic acids (c. $0.01 \mathrm{M}$ in buffer $\mathrm{pH} \mathrm{7.4)}$ with rabbitliver extract prepared as previously described (Bray, James, Ryman \& Thorpe, $1948 a$ ) gave rise to no liberation of diazotizable material beyond that formed by spontaneous hydrolysis in the controls. Similarly, $N$-phenylurea was not hydrolyzed by rabbit-kidney extract.

\section{Qualitative studies}

N-Phenylurea. The urine excreted by rabbits which had received phenylurea gave a purple colour with $\mathrm{FeCl}_{3}$, suggesting that an unconjugated phenolic compound was excreted. We were not able to isolate the compound responsible, however, by means of ether extraction at various values of $\mathrm{pH}$. The quantitative results given in Table 2 suggest that about half the dose might be excreted unahanged, but it was not possible to isolate $N$-phenylurea from the urine by extraction with either ether or methyl ethyl ketone. (The latter extracts $N$-phenylurea which has been added to urine.) A small amount of phenylurea was obtained during the isolation of the glucuronide (q.v.), but

\section{Table 2. Metabolism of N-phenylurea in the rabbit}

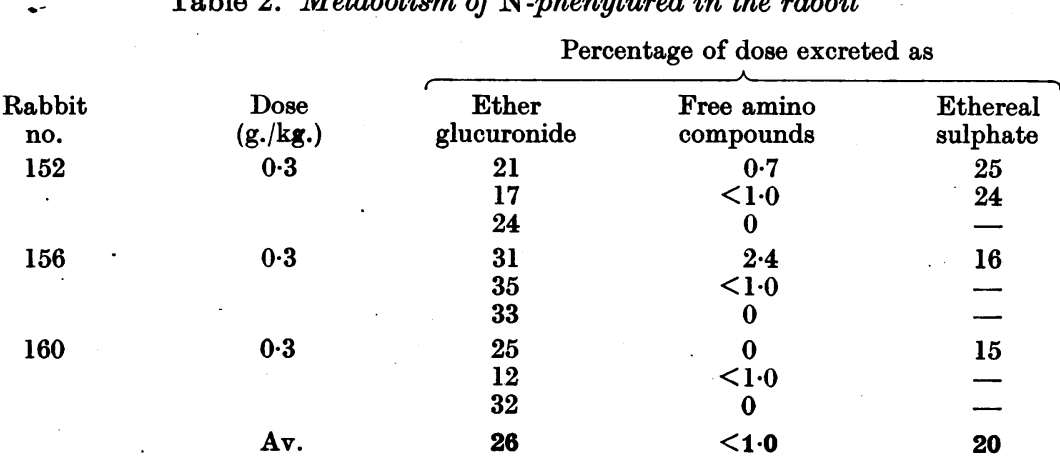


it was not possible to obtain an amount approximating to that unaccounted for.

Phenylurea urine was hydrolyzed with acid (cf. Bray \& Thorpe, 1948), neutralized and continuously extracted with ether. From 9.0 g. $N$-phenylurea given to ten rabbits 0.6 g. of a crystalline compound, m.p. $186^{\circ}$, was obtained. It gave a positive diazo reaction and a purple-brown colour with $\mathrm{FeCl}_{3}$. Mixed with an authentic specimen of $p$-aminophenol (m.p. $187^{\circ}$ ) it melted at $187^{\circ}$. The identity of the compound was further confirmed by comparing its $N$-acetyl derivative (m.p. $168^{\circ}$ ) with authentic $p$-acetamidophenol (m.p. $169^{\circ}$ ). The mixed m.p. was $169^{\circ}$. In the diazo tests on the crude extract a yellow colour was obtained with $\mathrm{HNO}_{2}$; it was thought that this might be due to the presence of an o-aminophenol derivative, but attempts at its isolation were unsuccessful.
From 6 g. phenylurea given to six rabbits a glucuronide was isolated as previously described (Bray et al. 1947) from which a crystalline potassium salt $(150 \mathrm{mg}$.) was obtained, as described by Morinaka (1922) and Tsunoo (1935). The properties are given and compared in Table 6 with those of the compounds obtained by the Japanese workers. We were unable to isolate $N$-( $p$-hydroxyphenyl)urea by the hydrolysis of the glucuronide, but on sublimation of the potassium salt with soda lime, $p$-aminophenol was obtained and identified as previously described. The glucuronide did not form a crystalline barium salt. During an attempt to isolate the glucuronide through its barium salt a small amount of $N$-phenylurea was isolated.

o-Tolylurea. Extraction of neutral $o$-tolylurea urine with ether gave a small quantity of crystals, m.p. $190^{\circ}$, which were identified as 0 -tolylurea. Yield, $8 \%$ of the dose. The

Table 3. Metabolism of o-tolylurea in the rabbit

\begin{tabular}{|c|c|c|c|c|c|c|}
\hline \multirow{2}{*}{$\begin{array}{c}\text { Rabbit } \\
\text { no. }\end{array}$} & \multirow{2}{*}{$\begin{array}{c}\text { Dose } \\
\text { (g./kg.) }\end{array}$} & \multicolumn{5}{|c|}{ Percentage of dose excreted as } \\
\hline & & $\begin{array}{l}\text { Ether-soluble } \\
\text { acid }\end{array}$ & $\begin{array}{c}\text { Ester } \\
\text { glucuronide }\end{array}$ & $\begin{array}{c}\text { Ether } \\
\text { glucuronide }\end{array}$ & $\begin{array}{l}\text { Free amino } \\
\text { compounds }\end{array}$ & $\begin{array}{l}\text { Ethereal } \\
\text { sulphate }\end{array}$ \\
\hline 152 & $0 \cdot 3$ & $\begin{array}{l}0 \\
0 \\
0 \\
0\end{array}$ & $\begin{array}{l}0 \\
0 \\
0 \\
0\end{array}$ & $\begin{array}{l}28 \\
10 \\
28 \\
38\end{array}$ & $\begin{array}{l}<1.0 \\
1.4 \\
<1.0\end{array}$ & $\frac{6}{--}$ \\
\hline 156 & $0 \cdot 3$ & $\begin{array}{r}0 \\
15 \\
0 \\
0\end{array}$ & $\begin{array}{l}0 \\
0 \\
0 \\
0\end{array}$ & $\begin{array}{l}33 \\
17 \\
37 \\
32\end{array}$ & $\begin{array}{l}<1.0 \\
\frac{1.8}{<1.0}\end{array}$ & $\begin{array}{l}- \\
- \\
-\end{array}$ \\
\hline 166 & $0 \cdot 3$ & $\begin{array}{l}0 \\
0 \\
0 \\
0\end{array}$ & $\begin{array}{l}0 \\
0 \\
0 \\
0\end{array}$ & $\begin{array}{l}28 \\
19 \\
44 \\
30\end{array}$ & $\begin{array}{l}<1.0 \\
<1.0 \\
<1.0\end{array}$ & $\frac{-}{5}$ \\
\hline $\mathrm{i} 68$ & $0 \cdot 3$ & $\begin{array}{r}12 \\
27 \\
0 \\
8\end{array}$ & $\begin{array}{l}0 \\
0 \\
0 \\
0\end{array}$ & $\begin{array}{l}56 \\
20 \\
31 \\
37\end{array}$ & $\begin{array}{l}<1.0 \\
\frac{1}{1.7} \\
<1.0\end{array}$ & $\begin{array}{c}- \\
- \\
-\end{array}$ \\
\hline & Av. & $4^{*}$ & $\mathbf{0}$ & 31 & $<\mathbf{1 \cdot 0}$ & 4 \\
\hline
\end{tabular}

* Since there is no other evidence of oxidation of the methyl group it seems likely that the positive values in this column are due to abnormal fluctuations in the base-line values, and that the true figure here is 0.

Table 4. Metabolism of m-tolylurea in the rabbit

Percentage of dose excreted as

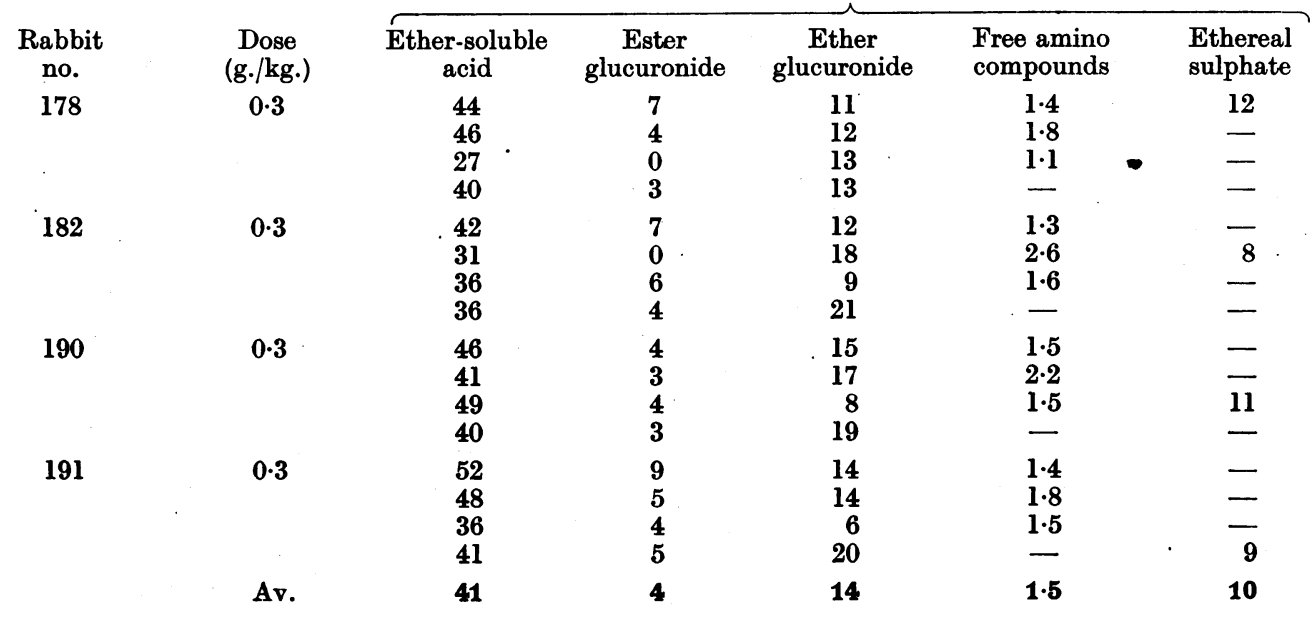


Table 5. Metabolism of p-tolylurea in the rabbit

\begin{tabular}{|c|c|c|c|c|c|c|}
\hline . & & \multicolumn{5}{|c|}{ Percentage of dose excreted as } \\
\hline $\begin{array}{c}\text { Rabbit } \\
\text { no. }\end{array}$ & $\begin{array}{c}\text { Dose } \\
\text { (g./kg.) }\end{array}$ & $\begin{array}{l}\text { Ether-soluble } \\
\text { acid }\end{array}$ & $\begin{array}{c}\text { Ester } \\
\text { glucuronide }\end{array}$ & $\begin{array}{c}\text { Ether } \\
\text { glucuronide }\end{array}$ & $\begin{array}{l}\text { Free amino } \\
\text { compounds }\end{array}$ & $\begin{array}{l}\text { Ethereal } \\
\text { sulphate }\end{array}$ \\
\hline 152 & $0 \cdot 3$ & $\begin{array}{r}52 \\
81 \\
+\quad 65 \\
88\end{array}$ & $\begin{array}{l}2 \\
4 \\
4 \\
-\end{array}$ & $\begin{array}{c}0 \\
0 \\
0 \\
-\end{array}$ & $\begin{array}{l}2 \cdot 3 \\
1 \cdot 7 \\
2 \cdot 2 \\
-\end{array}$ & $\frac{0}{-}$ \\
\hline 156 & $0 \cdot 3$ & $\begin{array}{l}85 \\
78 \\
79 \\
85\end{array}$ & $\begin{array}{l}5 \\
8 \\
8 \\
-\end{array}$ & $\begin{array}{l}0 \\
0 \\
0 \\
\end{array}$ & $\begin{array}{l}2 \cdot 1 \\
2 \cdot 8 \\
2 \cdot 1 \\
-\end{array}$ & $\frac{1}{-}$ \\
\hline 160 & $0 \cdot 3$ & - & $\begin{array}{l}8 \\
7 \\
5\end{array}$ & $\begin{array}{l}\mathbf{0} \\
0 \\
0\end{array}$ & $\begin{array}{l}2 \cdot 9 \\
1 \cdot 7 \\
1 \cdot 8\end{array}$ & $\frac{-}{0}$ \\
\hline 168 & $0 \cdot 3$ & $\begin{array}{l}96 \\
80 \\
87\end{array}$ & - & - & - & - \\
\hline . & Av. & 80 & 6 & $\mathbf{0}$ & $2 \cdot 2$ & $\mathbf{0}$ \\
\hline
\end{tabular}

Table 6. Properties of potassium salts of 4-ureidophenylglucuronide

\begin{tabular}{|c|c|c|}
\hline & $\begin{array}{c}\text { From } N \text {-phenylurea } \\
\text { in rabbit }\end{array}$ & $\begin{array}{l}\text { From 'Elbon'* } \\
\text { in rabbit }\end{array}$ \\
\hline $\begin{array}{l}\% \mathrm{~N} \\
\% \mathrm{~K} \\
{[\alpha]_{D} \text { in water }\left(^{\circ}\right)} \\
\mathrm{M} . \mathrm{p} .(\text { decomp. })\left({ }^{\circ}\right)\end{array}$ & $\begin{array}{c}7 \cdot 69 \\
10 \cdot 70 \\
-70 \cdot 1 \text { at } 23 \\
257\end{array}$ & $\begin{array}{c}7 \cdot 59 \\
10 \cdot 62 \\
-74 \cdot 99 \text { at } 20 \\
231\end{array}$ \\
\hline
\end{tabular}

urine was acidified and re-extracted, but only hippuric acid was isolated. No acetotoluidide was detected.

Extraetion of neutral, hydrolyzed urine gave a crystailline product which darkened rapidly. Treatment with charcoal and recrystallization from aqueous ethanol containing $\mathrm{SO}_{2}$ gave $50 \mathrm{mg}$. light yellow crystals, m.p. $178^{\circ}$, which gave a red-purple coloration with $\mathrm{FeCl}_{3}$ and positive diazo and indophenol reactions: mixed with an authentic specimen of 2-amino-5-hydroxytoluene (m.p. $179^{\circ}$ ), m.p. $179^{\circ}$. The acetate of the compound isolated (m.p. $125^{\circ}$ ) gave a blueviolet colour with $\mathrm{FeCl}_{3}$ and was shown to be identical with an authentic specimen of 2-acetamido-5-hydroxytoluene.

Crystalline barium or potassium salts of the glucuronide could not be obtained and attempts to obtain a crystalline glucuronide were unsuccessful, the product being a syrup: On hydrolysis of this with $2 \mathrm{~N}-\mathrm{HCl} 50 \mathrm{mg}$. of crystals, m.p. $230^{\circ}$, were obtained. The identity of this compound with $N$-(4-hydroxy-2-methylphenyl)urea was shown by comparison with an autthentic specimen. (Found: N, 16.6. Calc. for $\mathrm{C}_{8} \mathrm{H}_{10} \mathrm{~N}_{2} \mathrm{O}_{2}: \mathrm{N}, 16 \cdot 89 \%$.)

$\mathrm{m}$-Tolylurea. Ether extraction of $m$-tolylurea urine as collected yielded no product, but from the acidified (pH 1.5) urine a compound, m.p. $290^{\circ}$ (decomp.), was obtained in a yield corresponding to $25 \%$ of the dose administered. The compound had the same properties as synthetic $m$-ureidobenzoic acid and contained $15.6 \% \mathrm{~N}$; calc. for $\mathrm{C}_{8} \mathrm{H}_{8} \mathrm{~N}_{2} \mathrm{O}_{3}: \mathrm{N}, 15 \cdot 56 \%$. After hydrolysis for $2 \mathrm{hr}$. with $2 \mathrm{~N}-\mathrm{HCl}$, extraction with ether gave a crystalline product, m.p. $177^{\circ}$, which was shown to be identical with authentic $m$-aminobenzoic acid, and its identity was further confirmed by comparison of the $N$-acetyl derivatives. It is, therefore, concluded that the compound originally isolated

\begin{tabular}{|c|c|c|}
\hline \multicolumn{2}{|c|}{ From 'Ethynal' $\dagger$} & \multirow{2}{*}{$\begin{array}{c}\text { Calc. for } \\
\mathrm{C}_{13} \mathrm{H}_{15} \mathrm{~N}_{2} \mathrm{O}_{8} \mathrm{~K}\end{array}$} \\
\hline In dog & In rabbit & \\
\hline $\begin{array}{c}7 \cdot 5 \\
11 \cdot 07 \\
-67 \cdot 8 \text { at } 29 \\
243\end{array}$ & $\begin{array}{l}7 \cdot 31 \\
-59 \cdot 3 \text { at } 23 \\
-531\end{array}$ & $\begin{array}{c}7 \cdot 65 \\
10 \cdot 68 \\
- \\
-\end{array}$ \\
\hline$\dagger$ Tsunoc & & \\
\hline
\end{tabular}

was $m$-ureidobenzoic acid. No $m$-acetotoluidide or toluidine was isolated.

Ether extraction of neutral, hydrolyzed $m$-tolylurea urine yielded yellow-brown crystals, m.p. $174^{\circ}$, which gave with $\mathrm{FeCl}_{3}$ a red-brown colour, changing slowly to redpurple, and a positive indophenol reaction. On diazotizing and coupling with $N$-(l-naphthyl)ethylenediamine dihydrochloride a pale blue colour slowly giving place to purple was observed, which is characteristic of some aminocresols, e.g. 5-amino-2-hydroxytoluene, 2-amino-5-hydroxytoluene. Yield, $40 \mathrm{mg}$. from four doses of $0.9 \mathrm{~g}$. This compound was identical with an authentic specimen of 5-amino2-hydroxytoluene (m.p. $175^{\circ}$ ), mixed m.p. $174^{\circ}$. Its acetyl derivative melted at $180^{\circ}$, and did not depress the melting point of a synthetic specimen of 5-acetamido-2-hydroxytoluene. This does not give a colour with $\mathrm{FeCl}_{3}$. (Found: $\mathrm{N}, 8 \cdot 31$. Calc. for $\mathrm{C}_{9} \mathrm{H}_{11} \mathrm{NO}_{2}: \mathrm{N}, 8 \cdot 48 \%$.)

Attempts to obtain a crystalline glucuronide (or salt) were unsuccessful, only a syrup being obtained. The syrup was hydrolyzed by refluxing for $2 \mathrm{hr}$. with $2 \mathrm{~N}-\mathrm{HCl}$ and extracted with ether. The ether-soluble material was divided into two parts. From one 5-amino-2-hydroxytoluene was obtained and identified as above: the other part was acetylated, giving 5-acetamido-2-hydroxytoluene and $m$ acetamidobenzoic acid. This finding is in agreement with the results shown in Table 4, indicating the presence of both ester and ether type glucuronides. After several attempts to obtain $N$-(4-hydroxy-3-methylphenyl)urea by milder hydrolysis of the glucuronide syrup ( $20 \mathrm{~min}$. on boiling water bath with $\mathrm{N}-\mathrm{HCl}$ ), about $5 \mathrm{mg}$. straw-coloured needles, m.p. $195^{\circ}$, were obtained in one experiment. These gave a brown colour with $\mathrm{FeCl}_{3}$ and, after hydrolysis, indophenol 
and diazo reactions similar to those given by 5 -amino-2. hydroxytoluene. Mixed m.p. with authentic $N$-(4-hydroxy3-methylphenyl)urea (m.p. $198^{\circ}$ ), $195^{\circ}$. The amount was insufficient for purification for analysis. Small amounts of $m$-tolylurea were also obtained.

p-Tolylurea. Extraction of acidified $p$-tolylurea urine yielded an acid which did not melt below $300^{\circ}$. Yield $1.2 \mathrm{~g}$. from a total dose of $3.6 \mathrm{~g}$. After recrystallization from aqueous ethanol it was found to contain $16.0 \% \mathrm{~N}$. (Calc. for $\mathrm{C}_{8} \mathrm{H}_{8} \mathrm{~N}_{2} \mathrm{O}_{3}: \mathrm{N}, 15 \cdot 56 \%$.) Acid hydrolysis gave a crystalline product, m.p. $187^{\circ}$, which was shown to be identical with $p$-aminobenzoic acid (m.p. $189^{\circ}$ ); mixed m.p. $189^{\circ}$. This was confirmed by comparison of the acetamido compounds. It is, therefore, concluded that the product isolated from urine was $p$-ureidobenzoic acid. No other metabolite was isolated.

\section{DISCUSSION}

Table 7 summarizes the quantitative results obtained in this investigation, together with the corresponding results obtained with acetotoluidides (Bray \& Thorpe, 1948). It can be seen that the metabolic fates of the two types of compound are very similar, the main differences being quantitative rather than qualitative, e.g. the percentage conjugation of the hydroxylation products with sulphuric and glucuronic acids.

Although the ureido group in the compounds studied appears to be stable in vivo, as evidenced by the fact that various metabolites were isolated with it intact, the tendency to spontaneous decomposition suggests that some hydrolysis might be expected to occur. It is theoretically possible that amino compounds arising in this way may be acetylated before excretion. Attempts were made to identify acetamidobenzoic acids and acetotoluidides among the excretion products, in every case without success. Owing to the difficulties of distinguishing between and separating $N$-phenylurea derivatives and acetamido compounds, we do not regard the question as having been finally settled, although enzyme experiments lend support to the view that the ureido group is stable in vivo.

Other compounds in which a ureido group is attached directly to the aromatic ring do not appear to have been investigated, but the literature provides some information as to the stability of this group attached to aliphatic or other residues. Koehne (1895) stated that biuret was excreted unchanged by the dog, and Grebler \& Keltch (1926) found over $50 \%$ of hydantoin or hydantoic acid was excreted by the dog as hydantoic acid, there being no evidence of further breakdown. Several diphenylhydantoins, however, are excreted by man and dog as the diphenylhydantoic acids, and, to a much greater extent, as the corresponding $\alpha$-aminodiphenylacetic acids (Hine \& Kozelka, 1943). Benzoylurea (Koehne, 1895) and benzylidenediureide (Bülow, 1894) in the dog appear to lose the ureido group intact with the formation of urea.

The hydroxylation products of the tolylureas resemble exactly those from the acetotoluidides, all their constitutions being in agreement with the general rule suggested previously (Bray et al. 1948b). It is clear, therefore, that modification of the aromatic amino group by conversion to a ureido group does not change the nature of its influence on the position taken up by the entering hydroxyl group.

\section{SUMMARY}

1. The metabolism of the three $N$-tolylureas in the rabbit has been shown to be similar to that of the corresponding acetotoluidides.

2. The ureido group in these compounds appears to be stable in the rabbit and to rabbit-liver extracts in vitro.

3. $o$-Tolylurea is converted to $N$-(4-hydroxy-2methylphenyl)urea (35\% of the dose) which is excreted as ethereal sulphate $(4 \%)$ and glucuronide $(31 \%)$. The methyl group is not oxidized to any

Table 7. Comparison of metabolism of $\mathrm{N}$-tolylureas, acetotoluidides and $\mathrm{N}$-phenylurea in the rabbit

Percentage of compound

\section{(}

Compound

$N$-o-Tolylurea

$o$-Acetotoluidide*

$N$-m-Tolylurea

$m$-Acetotoluidide*

$N$ - $p$-Tolylurea

$p$-Acetotoluidide*

$N$-Phenylurea

\begin{tabular}{|c|c|c|c|c|c|c|}
\hline $\begin{array}{l}\text { Excreted } \\
\text { as ether- } \\
\text { soluble } \\
\text { acid }\end{array}$ & $\begin{array}{l}\text { Excreted } \\
\text { as ester } \\
\text { glucuronide }\end{array}$ & $\begin{array}{l}\text { Oxidized to } \\
\text { carboxylic } \\
\text { acid }\end{array}$ & $\begin{array}{l}\text { Excreted } \\
\text { as ether } \\
\text { glucuronide }\end{array}$ & $\begin{array}{l}\text { Excreted } \\
\text { as ethereal } \\
\text { sulphate }\end{array}$ & $\begin{array}{c}\text { Hydroxy- } \\
\text { lated }\end{array}$ & $\begin{array}{c}\text { Excreted } \\
\text { with free } \\
\text { amino group } \S\end{array}$ \\
\hline 0 & 0 & 0 & 31 & 4 & 35 & $<1 \cdot 0$ \\
\hline 8 & - & $6 \dagger$ & - & 32 & $32 \ddagger$ & $5 \cdot 6$ \\
\hline 41 & 4 & 45 & 14 & 10 & 24 & 1.5 \\
\hline 34 & - & $25 \dagger$ & - & 10 & $10 \ddagger$ & Trace \\
\hline 80 & 6 & 86 & 0 & 0 & 0 & $2 \cdot 2$ \\
\hline 78 & 10 & $96 \dagger$ & - & 0 & $0 \neq$ & 0.8 \\
\hline - & 0 & - & 26 & 20 & 46 & $<1.0$ \\
\hline
\end{tabular}

* Bray \& Thorpe (1948).

+ From total diazotizable material.

¥ May be low since no ether glucuronide value is included.

$\S$ All the values recorded in this column, with the exception of that for $o$-acetotoluidide, are probably due to spontaneous hydrolysis. The acetotoluidides hydrolyze spontaneously, although to a smaller extent than does $N$-phenylurea (Bray, Lake \& Thorpe, unpublished). 
appreciable extent. Some o-tolylurea is excreted unchanged.

4. $m$-Tolylurea is oxidized to $m$-ureidobenzoic acid $(45 \%), 4 \%$ of which is excreted as ester glucuronide, and hydroxylated to $N$-(4-hydroxy-3methylphenyl)urea (24\%), of which $10 \%$ is excreted as ethereal sulphate and $14 \%$ as ether glucuronide. Some $m$-tolylurea is excreted unchanged.

5. $p$-Tolylurea is almost completely oxidized to $p$-ureidobenzoic acid $(86 \%)$, of which only $6 \%$ is conjugated as ester glucuronide, the remainder being excreted free.
6. $N$-Phenylurea is partly hydroxylated to $N-(p$ hydroxyphenyl)urea (46\%) which is conjugated almost equally with sulphuric acid $(20 \%)$ and glucuronic acid $(26 \%)$. Some $N$-phenylurea is excreted unchanged. 4-Ureidophenylglucuronide was isolated from $N$-phenylurea urine as its crystalline potassium salt.

We are indebted to the Royal Society for a Government Grant which defrayed part of the cost of this work. The microanalyses were carried out by Drs Weiler and Strauss, Oxford.

\title{
REFERENCES
}

Bratton, A. C. \& Marshall, E. K. jun. (1939). J. biol. Chem. 128, 537.

Bray, H. G., James, S. P., Ryman, B. E. \& Thorpe, W. V. (1948a). Biochem. J. 42, 274.

Bray, H. G., Lake, H. J., Neale, F. C., Thorpe, W. V. \& Wood, P. B. $(1948 b)$. Biochem. J. 42, 434.

Bray, H. G., Neale, F. C. \& Thorpe, W. V. (1946). Biochem. J. 40, 406.

Bray, H. G., Ryman, B. E. \& Thorpe, W. V. (1947). Biochem. J. 41, 212.

Bray, H. G. \& Thorpe, W. V. (1948). Biochem. J. 43, 211.

Bruce, H. M. \& Parkes, A. S. (1946). J. Hyg., Camb., 44, 501.

Bülow, K. (1894). Pflüg. Arch. ges. Physiol. 57, 93.

Friedmann, E. (1931). Biochem. Z. 242, 266.

Gaebler, O. H. \& Keltch, A. K. (1926). J. biol. Chem. 70, 763.
Hine, C. H. \& Kozelka, F. L. (1943). J. Pharmacol. 77, 175, 180.

Horn, F. (1936). Hoppe-Seyl. Z. 242, 23.

Horn, F. (1937). Hoppe-Seyl. Z. 249, 82.

Jaffé. M. \& Hilbert, P. (1888). Hoppe-Seyl. Z. 12, 295.

Koehne, F. (1895). Jber. Fortschr. Physiol. 3, 259.

Mitsuba, K. \& Ichihara, K. (1927). Hoppe-Seyl. Z. 164, 244.

Morinaka, K. (1922). Hoppe-Seyl. Z. 124, 247.

Mörner, K. A. H. (1889). Hoppe-Seyl. Z. 13, 12.

Müller, F. (1887). Dtsch. med. Wschr. 13, 24.

Pruszynski, J. (1893). Jber. Fortschr. Tierchem. 22, 76.

Salkowski, E. (1873). Ber. dtsch. chem. Ges. 6, 744.

Salkowski, E. (1882). Hoppe-Seyl. Z. 7, 93.

Schmidt, C. L. A. \& Allen, E. G. (1920). J. biol. Chem. 42, 55.

Schmiedeberg, O. (1878). Arch. exp. Path. Pharmak. 8, 1. Tsunoo, S. (1935). J. Biochem., Tokyo, 22, 409.

Ville, J. (1892). C.R. Acad. Sci., Paris, 114, 228.

\section{The Effect of Deamination and Esterification on the Reactivity of Collagen}

\author{
By JOANE H. BOWES AND R. H. KENTEN \\ The British Leather Manufacturers' Research Association, London, S.E. 1
}

(Received 11 June 1948)

The most important reactive groups in collagen are amino, guanidino and carboxyl, all of which are present in comparatively large numbers; few phenolic, hydroxyl and imidazole groups are present and indole groups are absent (Bowes \& Kenten, 1948a). A study has now been made of the effect of modification of the amino, guanidino and carboxyl groups on the acid- and base-binding capacity, and on the swelling of collagen. The combination of the modified collagens with vegetable tannins, basic chromium salts and formaldehyde has also been investigated primarily because of the importance of these three classes of compound in the conversion of collagen to leather. Moreover, the fixation of metals by proteins is of general interest, and information concerning the factors affecting the fixation of tannins may help to throw light on the association of tannins and proteins in nature.

The amino groups of proteins can readily be converted to hydroxyl groups by the action of. nitrous acid. The reaction is not entirely specific, however, since at low $\mathrm{pH}$ values, or if the reaction is prolonged, modification of the guanidino, imidazole, tyrosine and glutamide groups may also take place (for review of literature see Olcott \& FraenkelConrat, 1947). With soluble proteins, reaction with the amino groups is rapid and other reactions are probably negligible, but with fibrous proteins, such 